University of Nebraska - Lincoln

DigitalCommons@University of Nebraska - Lincoln

USGS Staff -- Published Research

US Geological Survey

2014

\title{
Comparative responses to endocrine disrupting compounds in earlylife stages of Atlantic salmon, Salmo salar
}

\section{T.A. Duffy}

USGS, Conte Anadromous Fish Research Center, tduffy@lumcon.edu

L. R. Iwanowics

USGS, Leetown Science Center, Fish Health Branch

S. D. McCormick

USGS, Conte Anadromous Fish Research Center

Follow this and additional works at: http:// digitalcommons.unl.edu/usgsstaffpub

Duffy, T. A.; Iwanowics, L. R.; and McCormick, S. D., "Comparative responses to endocrine disrupting compounds in earlylife stages of Atlantic salmon, Salmo salar" (2014). USGS Staff -- Published Research. 822.

http:// digitalcommons.unl.edu/usgsstaffpub/822

This Article is brought to you for free and open access by the US Geological Survey at DigitalCommons@University of Nebraska - Lincoln. It has been accepted for inclusion in USGS Staff -- Published Research by an authorized administrator of DigitalCommons@University of Nebraska - Lincoln. 


\title{
Comparative responses to endocrine disrupting compounds in early life stages of Atlantic salmon, Salmo salar
}

\author{
T.A. Duffy ${ }^{\mathrm{a}, *}$, L.R. Iwanowicz ${ }^{\mathrm{b}}$, S.D. McCormick ${ }^{\mathrm{a}}$ \\ a USGS, Conte Anadromous Fish Research Center, 1 Migratory Way, Turners Falls, MA 01376, United States \\ ${ }^{\mathrm{b}}$ USGS, Leetown Science Center, Fish Health Branch, 11649 Leetown Road, Kearneysville, WV 25430, United States
}

\section{A R T I C L E I N F O}

\section{Article history:}

Received 21 January 2014

Received in revised form 13 March 2014

Accepted 19 March 2014

Available online 28 March 2014

\section{Keywords:}

Endocrine disruptor

Estradiol

Nonylphenol

Atlantic salmon

Vitellogenin

Life stage

\begin{abstract}
A B S T R A C T
Atlantic salmon (Salmo salar) are endangered anadromous fish that may be exposed to feminizing endocrine disrupting compounds (EDCs) during early development, potentially altering physiological capacities, survival and fitness. To assess differential life stage sensitivity to common EDCs, we carried out short-term ( 4 day) exposures using three doses each of $17 \alpha$-ethinylestradiol (EE2), $17 \beta$-estradiol (E2), and nonylphenol (NP) on four early life stages; embryos, yolk-sac larvae, feeding fry and 1 year old smolts. Differential response was compared using vitellogenin (Vtg, a precursor egg protein) gene transcription. Smolts were also examined for impacts on plasma Vtg, cortisol, thyroid hormones $\left(\mathrm{T}_{4} / \mathrm{T}_{3}\right)$ and hepatosomatic index (HSI). Compound-related mortality was not observed in any life stage, but Vtg mRNA was elevated in a dose-dependent manner in yolk-sac larvae, fry and smolts but not in embryos. The estrogens EE2 and E2 were consistently stronger inducers of Vtg than NP. Embryos responded significantly to the highest concentration of EE2 only, while older life stages responded to the highest doses of all three compounds, as well as intermediate doses of EE2 and E2. Maximal transcription was greater for fry among the three earliest life stages, suggesting fry may be the most responsive life stage in early development. Smolt plasma Vtg was also significantly increased, and this response was observed at lower doses of each compound than was detected by gene transcription suggesting plasma Vtg is a more sensitive indicator at this life stage. HSI was increased at the highest doses of EE2 and E2, and plasma $\mathrm{T}_{3}$ was decreased at the highest dose of EE2. Our results indicate that all life stages are potentially sensitive to endocrine disruption by estrogenic compounds and that physiological responses were altered over a short window of exposure, indicating the potential for these compounds to impact fish in the wild.
\end{abstract}

(c) 2014 Published by Elsevier B.V.

\section{Introduction}

Environmental contaminants are potentially one of several factors that contributed to the decline of Atlantic salmon (Salmo salar) on the east coast of North America, and may currently play a role in poor recruitment success and restoration of this species (Fairchild et al., 1999). In particular, endocrine disrupting compounds (EDCs) are an increasing concern for wildlife, since population-level impacts of these compounds have been documented (Kidd et al., 2007; Lange et al., 2011; Blazer et al., 2012). Endocrine disrupting compounds are most often associated with municipal and industrial wastewater effluent, can feminize male fish in receiving waters (Sumpter, 2005; Desbrow et al., 1998; Blazer et al., 2007), and lead to local extinction (Kidd et al., 2007).

\footnotetext{
* Corresponding author. Present address: Louisiana Universities Marine Consortium, 8124 Highway 56, Chauvin, LA 70344, United States. Tel.: +1 2164089564.

E-mail addresses: tduffy@lumcon.edu, taraannduffy@gmail.com (T.A. Duffy).
}

Two of the most prevalent estrogenic compounds in rivers and estuaries include the natural steroid, $17 \beta$-estradiol (E2), and a synthetic estrogen, $17 \alpha$-ethinylestradiol (EE2) (Desbrow et al., 1998). Plasticizers such as 4-nonylphenol (NP) are also present in effluent, and act as weak feminizing compounds in fish (Servos et al., 2003). Routine wastewater treatment does not completely remove these compounds (Johnson and Sumpter, 2001), and fish in receiving waters exhibit histological evidence of feminization, biased sex ratios, and developmental abnormalities (Oberdorster and Cheek, 2001; Matthiessen, 2003; Bernanke and Koehler, 2009; Leet et al., 2011).

Exposure to EDCs can elicit severe and long-lasting impacts, primarily when fish are exposed early in development (Strussmann and Nakamura, 2002; Mills and Chichester, 2005). Several studies demonstrate that particular developmental stages are more vulnerable to EDCs than others. For example, Liney et al. (2005) exposed the common roach, Rutilus rutilus, to a gradient of wastewater effluent and found little response in adults but $100 \%$ feminization in fish exposed during the embryonic through juvenile period. Atlantic 
Table 1

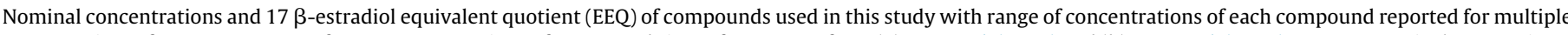

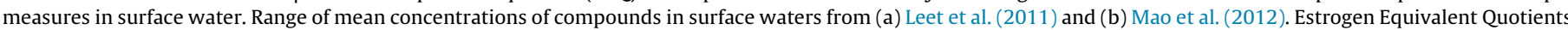
(EEQ) are means \pm S.E. from 2 to 8 samples collected across different life stages. BD-below the limit of detection (LOD) $E_{2}$ LOD $=4.5 \times 10^{-11}$, Sanseverino et al. (2005).

\begin{tabular}{|c|c|c|c|c|c|}
\hline \multirow[t]{2}{*}{ Compound } & & \multicolumn{4}{|c|}{ Nominal concentrations } \\
\hline & & $\mathrm{nM}$ & $\operatorname{ng~} \mathrm{l}^{-1}$ & $\operatorname{EEQ}\left(\mathrm{ng} \mathrm{l}^{-1}\right)$ & Surface waters \\
\hline \multirow[t]{3}{*}{$17 \alpha$-Ethinylestradiol (EE2) } & Low & 0.004 & 1.2 & $10.3 \pm 0.4$ & $0.04-28.6 \mathrm{ng} \mathrm{l}^{-1 \mathrm{a}}$ \\
\hline & Medium & 0.04 & 11.9 & $88.4 \pm 10.6$ & \\
\hline & High & 0.4 & 118.6 & $76.1 \pm 7.6$ & \\
\hline \multirow[t]{3}{*}{$17 \beta$-Estradiol (E2) } & Low & 0.04 & 10.9 & $7.6 \pm 0.5$ & $0.11-84.3 \mathrm{ng} \mathrm{l}^{-1 \mathrm{a}}$ \\
\hline & Medium & 0.4 & 109.0 & $61.2 \pm 6.7$ & \\
\hline & High & 4 & 1089.6 & $810.8 \pm 108.3$ & \\
\hline \multirow[t]{3}{*}{ Nonylphenol (NP) } & Low & 4 & 881.4 & $\mathrm{BD}$ & $15-30,000 \mathrm{ng} \mathrm{l}^{-1 \mathrm{~b}}$ \\
\hline & Medium & 40 & 8814.0 & $\mathrm{BD}$ & \\
\hline & High & 400 & 88140.0 & $13.5 \pm 0.7$ & \\
\hline
\end{tabular}

\footnotetext{
a Range of mean concentrations of compounds in surface waters, compiled by Leet et al. (2011).
}

b Approximate range of concentrations of NP compiled by Mao et al. (2012).

cod (Gadus morhua) embryos and larvae exposed to produced oil discharge water and E2 exhibit higher mortality and impacts to fitness than in fish exposed as post-metamorphic juveniles (Meier et al., 2010). Similar life stage-dependent effects have been demonstrated in zebrafish (Brion et al., 2004), medaka (Koger et al., 2000), and fathead minnow (van Aerle et al., 2002). Atlantic salmon have prolonged early life stage development, with specific biotic and abiotic requirements that are essential for normal development. Therefore, a better understanding of differential life stage sensitivity is important for management and conservation practices in areas where environmental contaminants may pose a threat to Atlantic salmon fitness and recruitment early in life.

Vitellogenin (Vtg) is a precursor egg yolk-protein that is often used as a biomarker of feminizing EDC exposure (Bernanke and Koehler, 2009; Leet et al., 2011). Elevated Vtg is normally associated with reproductive, spawning females (Tyler and Sumpter, 1996), and is often a more sensitive measure of contaminant exposure than phenotype or population-level responses (Leet et al., 2011). Vitellogenin production in juvenile or male fish, in particular, can be a very sensitive indicator of exposure to feminizing compounds at environmentally relevant concentrations (Leet et al., 2011). Elevated plasma concentrations of vitellogenin have been found in male and juvenile fish from sewage-impacted aquatic ecosystems around the world (Bernanke and Koehler, 2009), which supports the use of Vtg as a biomarker for estrogenic EDC exposure (Tyler and Routledge, 1998). Elevated plasma Vtg in fish has been associated with enlarged livers (Kaptaner et al., 2009), abnormal gonad development (Lye et al., 1997; Tyler and Jobling, 2008), and reduced growth (Woltering, 1984). It has also been used to compare sensitivities of multiple life stages to estrogenic exposure (Leet et al., 2011).

The objective of this study was to compare the vitellogenin response to three common endocrine disrupting compounds in four stages of Atlantic salmon development; embryos, yolk-sac larvae, feeding fry, and smolts (the downstream migratory phase of anadromous salmonids). Exposures were carried out at short-term (4 day) assessments, similar to whole effluent toxicity (WET) tests mandated by regulating agencies (Chapman, 2000). For each compound, we used a nominal dose that approximates a concentration that would be seen in an urbanized riverine system (low), a concentration seen in wastewater effluent (medium), and a positive control (high) along with a vehicle only control. Relative estrogenicity of treatments was compared with the bioluminescent yeast estrogen screen (BLYES; Sanseverino et al., 2005). We measured Vtg mRNA in all life stages, in addition to Vtg plasma concentration in smolts in which we could collect sufficient plasma volumes for analysis. In addition, we assessed potential secondary impacts to performance and stress in smolts in the form of hepatosomatic index, and the levels of thyroid hormone and cortisol which are important regulators of salinity performance in migrating Atlantic salmon (McCormick, 2001; Stefansson et al., 2012).

\section{Methods}

\subsection{Experimental methods}

Experiments were carried out using Atlantic salmon (Salmo salar) encompassing four life stages: late-stage embryos, newly hatched larvae, feeding fry, and smolts. All life stages were the progeny of sea run adults from the Connecticut River stock of Atlantic salmon, a population that is under active restoration. Treatments with embryos, yolk-sac larvae and feeding fry were carried out in $1.1 \mathrm{~L}$ aerated flow-through chambers with a $19 \mathrm{~L}$ head tank. In mid-February, twenty embryos (approximately 0.15 g each, roughly 2 weeks prior to hatch) were allocated to each chamber, two chambers per treatment and acclimated to $7{ }^{\circ} \mathrm{C}$ (to minimize the chance of temperature-induced malformations that occurs at temperatures $>11^{\circ} \mathrm{C}$, Poxton, 1991) over $72 \mathrm{~h}$ before exposures were conducted. Aerated, covered head tanks were refilled daily with dechlorinated city water and the compound of interest, ensuring a turnover of 7 times $\mathrm{d}^{-1}$ and an average flow rate of $0.25 \mathrm{Lh}^{-1}$. All exposures were carried out in a cold room to maintain temperature. Compounds (17 $\alpha$-ethinylestradiol (EE2), $17 \beta$-estradiol (E2) and 4-nonylphenol (NP)) were purchased from Sigma-Aldrich (St. Louis, MO) and all concentrations were converted to nanomolar for comparison (Table 1). All compounds used were solubilized in methanol (used as a vehicle for each compound) at a final concentration of $<0.0001 \%$ to minimize solvent toxicity (Lerner et al., 2007a). Control treatments received solvent only. At the end of $96 \mathrm{~h}$ embryos were anesthetized with MS-222 (Argent Laboratories, Redmond, WA), briefly weighed, then immediately snap-frozen on dry ice, and stored at $-80^{\circ} \mathrm{C}$ prior to analysis.

Yolk-sac larvae and feeding fry were exposed consecutively, following embryo exposures, and all animals were taken from the same batch of fish produced. Larvae and fry stages were exposed at $15^{\circ} \mathrm{C}$. Two-week post-hatch yolk-sac larvae (approximately $0.16 \mathrm{~g}$ ) were used in exposures in March 2011 at 18 fish per replicate, two replicates per treatment and feeding fry (approximately 1 month post yolk sac absorption) were exposed in early May, 2011 at 15 fish per replicate, two replicates per treatment. Both life stages were acclimated in the exposure chambers for $72 \mathrm{~h}$ prior to beginning of the experiment. Feeding fry (and $0.20 \pm 0.001 \mathrm{~g}$ and $30.7 \pm 0.1 \mathrm{~mm}$ ) were acclimated to pelleted salmon feed in the hatchery and fish were fed daily prior to and during the exposures. 
Waste was siphoned from experimental tanks daily to minimize bacterial degradation of contaminants.

Atlantic salmon parr from the Kensington Atlantic State Fishing Hatchery (CT, USA) were brought to the Conte Anadromous Fish Research Center in October 2010 and raised until fish were large enough in size to undergo smolting in the spring of 2011. These smolts were exposed to all compounds in three consecutive, 4-day experiments between April 5th and April 19th, 2011, during the predicted peak of smolting. Smolts $(15.9 \pm 1.1 \mathrm{~g}$ and $32.5 \pm 6.3 \mathrm{~cm})$ were placed in $30 \mathrm{~L}$ circular tanks at six fish per tank, two tanks per treatment, on the morning the exposures were initiated. Fish were not fed during the 4-day period to minimize potential aggressive interactions. Large, covered $560 \mathrm{~L}$ circular tanks served as head tanks, which were filled just prior to the beginning of the exposure period. Head tanks were replenished daily with the appropriate volume of stock contaminant in methanol mixed with dechlorinated city water, yielding a turnover time of at least 2 times $\mathrm{d}^{-1}$ and flow rate of approximately $10.5 \mathrm{~L} \mathrm{~h}^{-1}$.

Following the 96-h exposures, smolts were removed from experimental tanks, anesthetized with a lethal dose of MS-222, and immediately bled with heparinized syringes following collection of length and weight data. Fish were immediately placed on ice, and gill and liver tissues were removed, snap-frozen and stored at $-80{ }^{\circ} \mathrm{C}$ until analysis. No signs of precocious sexual maturation were observed. Photoperiod for all life stages was set to the natural light:dark cycle (between LD 10:14 and 14:10 from mid February through mid-May) for Turners Falls, MA. Four individuals per replicate (eight total per treatment) were randomly chosen for all analyses with each life stage.

\subsection{Relative estrogenicity of treatments}

Tank water samples were collected on the third day of exposure for analysis of relative estrogeniticy. Samples were collected in $50 \mathrm{ml}$ polypropylene tubes from all tanks, immediately frozen at $-80^{\circ} \mathrm{C}$ and stored at $-20^{\circ} \mathrm{C}$. Samples for all NP treatments and the lowest EE2 and E2 treatments were subjected to solid phase extraction (SPE) using OASIS $^{\circledR}$ HLB $(200 \mathrm{mg}$ ) glass cartridges (Waters Corporation, Milford, MA), following a modified version of a method published by Lagana et al. (2004). Solid phase extraction and concentration was necessary for these treatments to ensure that estrogenicity could be measured with the bioluminescent yeast estrogen screen (BLYES; Sanseverino et al., 2005). All solvents were HPLC grade. Cartridges were sequentially pre-conditioned with $5 \mathrm{ml}$ each of: $100 \%$ ethyl acetate, 50:50 methanol:dichloromethane (DCM), 100\% methanol, and HPLCgrade water $\mathrm{pH} 3$. Each sample $(45 \mathrm{ml})$ was loaded onto the cartridge at a flow rate of $5-6 \mathrm{ml} / \mathrm{min}$ (continuous vacuum). Elution solvents consisted of $6 \mathrm{ml}$ methanol (fraction one) and $6 \mathrm{ml}$ of 50:50 methanol:DCM (fraction two). Five hundred microliters of $100 \%$ methanol were added to each glass tube to solubilize samples. Samples were then pooled and transferred to brown sample ampoules ( $1 \mathrm{ml}$ total).

The total concentration of estrogenic compounds in the water samples relative to $17 \beta$-estradiol (E2) (17 $\beta$-estradiol equivalent quotient (EEQ)) was estimated using the BLYES assay (Sanseverino et al., 2005). The BLYES assay was performed according to Ciparis et al. (2012) with strain BLYES provided by Dr. John Sanseverino (University of Tennessee) and maintained in a dormant stage at $4{ }^{\circ} \mathrm{C}$ in modified Yeast Minimal Media (YMM leu-, ura-; Routledge and Sumpter, 1996). For the assay, strain BLYES was brought to early stationary phase in YMM at $30^{\circ} \mathrm{C}$ on a rotary shaker to an approximate $\mathrm{OD}_{600}$ of 0.750 . The BLYES assay was performed in sterile, clear-bottom, black polystyrene 96-well assay plates (Costar, Corning Incorporated, Corning, NY). SPE extracted samples were diluted to $10 \%$ in YMM, and $100 \mu$ l of the diluted sample was added to each well in duplicate. Non-extracted samples were analyzed by adding $75 \mu \mathrm{l}$ of water sample to $25 \mu \mathrm{l}$ of $4 \times$ YMM. All assay plates included a 12-point standard curve consisting of E2 ranging from $2.3 \times 10^{-5}-0.50 \mu \mathrm{M}$ and sample blanks containing YMM only. Strain BLYES was added to all preloaded wells at a volume of $100 \mu \mathrm{l}$, resulting in a final sample dilution of $5 \%$. Plates (covered) were incubated in the dark at $30^{\circ} \mathrm{C}$ for $6 \mathrm{~h}$ on an orbital shaker. Luminescence was quantified using a Molecular Devices SpectraMax M4 in luminescence mode. Data was acquired and analyzed in SoftMaxPro 6.2. The $\mathrm{EC}_{50}[\mathrm{M}]$ values for E2, EE2 and NP as defined in the BLYES assay validation are $2.4 \times 10^{-10}, 2.5 \times 10^{-11}$ and $1.7 \times 10^{-5}$ respectively (Sanseverino et al., 2005).

\subsection{Atlantic salmon Vtg mRNA quantification}

Total RNA was extracted from whole animals (embryo, larvae, and feeding fry) or liver tissue (feeding fry and smolts) using a phenol-based extraction (Tri-Reagent, MRC, Cincinnati, OH, USA). RNA was DNAse treated (RQ1, Promega Corporation, Madison, WI, USA) and reverse transcribed with the High Capacity RNA-tocDNA master mix (Life Technologies, Carlsbad, CA) according to the manufacturers' instructions. Primers for salmon Vtg mRNA quantification and cycling conditions are described in Arukwe and Roe (2008). Primers and cycling conditions for the housekeeping gene (EF-1a) were taken from Ingerslev et al. (2006). Both primer sets were validated using the Roche 480 LightCycler (Roche Applied Science, Indianapolis, IN). Each primer set yielded optimal melting curves indicating the production of one amplicon ( $\sim 200$ base pairs) each. Briefly, qPCR analysis was carried out using LightCycler 480 SYBR Green I Master Mix (Roche Applied Science) in $12 \mu \mathrm{l}$ reaction volumes with primers at $500 \mathrm{nM}$. No-template controls and negative reverse transcription controls were run on each plate and confirmed the absence of DNA contamination in the samples.

Plate to plate variation was accounted for by running a standard curve and control sample on each plate, and Vtg mRNA was calculated from the plate-specific standard curve. Duplicate $\mathrm{Ct}$ values that differed by more than 0.5 cycles were removed from analysis ( $<2 \%$ of data). Data was expressed relative to EF- $1 \alpha$ and normalized to the control mean. Four individuals per replicate (eight total per treatment) were randomly chosen for all analyses and life stages.

\subsection{Vtg enzyme immunoassay (EIA)}

A quantitative and sensitive EIA was developed from the methods outlined in Peck et al. (2011) using a polyclonal, rabbit anti-Atlantic salmon Vtg antibody, AA-1 (Biosense Laboratories AS, Bergen, Norway). Costar, 96-well microtiter plates (\#3369, Corning Life Sciences, Tewksbury, MA) were coated with $60 \mathrm{ng} / \mathrm{ml}$ Atlantic salmon vitellogenin (\#9902, Biosense Laboratories, Bergen, Norway) in $0.05 \mathrm{M} \mathrm{Na}_{2} \mathrm{CO}_{3}$ and incubated overnight at $4{ }^{\circ} \mathrm{C}$. The following day, plates were washed with cold phosphate-buffered saline (PBS) with 0.05\% Tween-20 (Sigma-Aldrich), pH 7.2 (PBST) and blocked with PBST with $2 \%$ milk powder overnight at $4{ }^{\circ} \mathrm{C}$. Samples or standards were mixed with the primary antibody (in PBST with $1 \%$ milk powder). Samples were diluted a minimum of $1: 100$ to minimize interference and false-positive readings where Vtg was low (Peck et al., 2011) up to $1: 10,000$ for samples with high Vtg content. These were mixed at $4{ }^{\circ} \mathrm{C}$ overnight on a rotary shaker. On the final day, the plate was washed with PBST, incubated with samples or standards for $2 \mathrm{~h}$ at $37^{\circ} \mathrm{C}$. Plates were washed, then incubated with secondary antibody (goat anti-rabbit horseradish peroxidase conjugate $(\mathrm{G}(\mathrm{H}+\mathrm{L}))$ (KPL, Inc., Gaithersburg, MD) at $1: 2500$ for $45 \mathrm{~min}$ at $37^{\circ} \mathrm{C}$. Color development was carried out with TMB for 30 min then quenched with $1 \mathrm{~N} \mathrm{H}_{2} \mathrm{SO}_{4}$. Optical density was measured with a BioTek Synergy 2 spectrophotometer (BioTek, Winooski, VT) at $450 \mathrm{~nm}$. Parallelism was demonstrated between 
diluted samples and Vtg standard. Inter- and intra-assay variation were $4.9 \pm 1.5 \%( \pm \mathrm{SE})$ and $2.7 \pm 0.7 \%$, respectively. Assay was sensitive to Vtg concentration $<50 \mathrm{ng} / \mathrm{ml}$ ( $T$-test, $p<0.001$ ), indicated by significant difference from the zero standard.

\subsection{Additional physiological parameters}

Hepatosomatic index (HSI) of smolts was calculated as liver weight/total weight $\times 100$. Thyroxine $\left(T_{4}\right)$ and triiodothyronine $\left(\mathrm{T}_{3}\right)$ concentrations were measured by a direct radioimmunoassay (Dickhoff et al., 1979) as modified by McCormick et al. (1995). The range of the assays as defined by the standard curve was 1 to

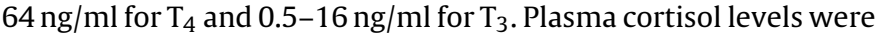
measured by a validated direct competitive enzyme immunoassay as outlined in Carey and McCormick (1998). Sensitivity of this assay was $0.3 \mathrm{ng} / \mathrm{ml}$ to $160 \mathrm{ng} / \mathrm{ml}$ and the lower detection limit was $0.3 \mathrm{ng} / \mathrm{ml}$. $\mathrm{Na}^{+} / \mathrm{K}^{+}$-ATPase activity in gill homogenates was determined using a temperature regulated microplate method (McCormick, 1993). In this assay, ouabain-sensitive $\mathrm{Na}^{+} / \mathrm{K}^{+}$-ATPase activity was measured by coupling the production of ADP to NADH using lactic dehydrogenase and pyruvate kinase in the presence and absence of $0.5 \mathrm{mmoll}^{-1}$ ouabain. Ten microliters of samples were run in duplicate in 96-well microplates at $25^{\circ} \mathrm{C}$ and read at a wavelength of $340 \mathrm{~nm}$ for $10 \mathrm{~min}$ on a BioTek Synergy 2 spectrophotometer (BioTek, Winooski, VT). Protein concentration of the homogenate was determined using a BCA protein assay (Thermo Fisher Scientific, Rockford, IL).

\subsection{Statistical analyses}

The housekeeping gene, EF- $1 \alpha$, demonstrated stable transcription during the fry and smolt stages among all doses of compounds (one-way ANOVA, $p=0.12$ and $p=0.25$, respectively). Some differential transcription of EF- $1 \alpha$ was noted during the embryo and larval stages, evidenced by a few significant differences in post hoc comparisons among compounds. Therefore, our analysis was restricted to comparisons of dosage within a single compound for each life stage (one-way ANOVA, Holm-Sidak post hoc comparisons). One significant difference was noted between EF- $1 \alpha$ in the control $v s$. NP $40 \mathrm{nM}$ treatment, but statistical analyses of $V t g$ transcription normalized to cDNA input yielded identical statistical interpretations when compared to the data normalized to $\mathrm{EF}-1 \alpha$. All statistical analyses were considered significant at $p<0.05$.

Vtg mRNA data did not differ statistically among replicates compared for yolk-sac larvae, feeding fry, or smolt exposures. A significant tank effect was noted for embryos, but this was limited to EE2 (one-way nested ANOVA, $p=0.002$ ). This effect was likely driven by high variability in responses during the embryo stages and low numbers of fish analyzed from each duplicate tank ( $n=8$ per treatment analyzed). All other replicate treatments demonstrated no statistically significant differences. Therefore, replicate tanks were combined for all analyses. All data were logtransformed for normality and homogeneity of variance where necessary. Treatment effects for all physiological measures were examined with one-way ANOVA with Holm-Sidak post hoc comparisons among individuals from duplicate tanks unless otherwise stated.

Atlantic salmon Vtg protein concentration was log-transformed for normality and treatments were compared with a two-way ANOVA with sex as the second factor. Hepatosomatic Index data did not meet assumptions of normality and equal variance following transformation, and data were compared using a one-way ANOVA on ranks with Dunn's post hoc comparisons. No sex-specific differences in the additional physiological parameters were observed.
All other physiological measures were compared with one-way ANOVA. All statistical analyses were carried out with SigmaPlot version 11.0 (Systat Software, San Jose, CA).

\section{Results}

Four-day (96-h) exposures were carried out on embryos, yolksac larvae, feeding fry and smolts with minimal mortality (life stage, mean mortality per replicate \pm S.E; embryo, $4.5 \pm 1 \%$; yolk-sac larvae, $1.1 \pm 1 \%$; feeding fry, $2.2 \pm 2 \%$; smolts, $0 \%$ mortality). Mortality was not dose- or treatment-dependent.

Relative estrogenicities of treatments (EEQs), as measured by the BLYES assay, were similar between the low and medium EE2 and E2 treatments but were low to undetectable for NP treatments as well as solvent-only controls (Table 1). Relative estrogenicity (EEQ or $17 \beta$-estradiol equivalence quotient), was most directly comparable to the nominal E2 treatment loading, and showed a log-scale dilution among treatments. EEQ values for E2 were approximately 26-44\% lower than expected based on the nominal E2 loading. EE2 and NP EEQ values were not directly comparable to the nominal concentrations of these two compounds due to estrogen receptor-specific differences in estrogenicity, but EE2 EEQ values most closely mimicked E2 values. EE2 did show a change in magnitude in EEQ values between the low and medium doses, and these EEQ values were similar in magnitude to the EEQ values for E2. However, the highest concentration of EE2 had an EEQ value that was lower than expected based on the nominal dose. NP low and medium EEQ values were below the detection limit, and the high dose of NP elicited a low EEQ response that was comparable to that of the low doses of EE2 and E2.

\subsection{Atlantic salmon Vtg mRNA}

All life stages demonstrated upregulation of Vtg mRNA in response to EDC's with maximal transcription in whole body comparisons occurring in feeding fry (one-way ANOVA with Holm-Sidak post hoc comparisons, Fig. 1). Embryos increased Vtg transcription in response to $0.4 \mathrm{nM} 17 \alpha$-ethinylestradiol, but lower concentrations of this compound, as well as $17 \beta$-estradiol and nonylphenol, did not induce a statistically significant vitellogenic response (Fig. 1A). Yolk-sac larvae Vtg transcription increased significantly and in a dose-dependent manner for the two highest concentrations of all three compounds (Fig. 1B). Feeding fry had a statistically similar response to the compounds compared to yolk-sac larvae, but the magnitude of transcriptional upregulation was greater for feeding fry $(\sim 500$ times greater than control) than for yolk-sac larvae ( 200 times greater than control) (Fig. 1C). Smolt liver tissue demonstrated similar dose-dependent Vtg mRNA upregulation for both $17 \alpha$-ethinylestradiol and $17 \beta$-estradiol, whereas a reduction in Vtg mRNA (relative to the control) was observed for fish exposed to 40 and $400 \mathrm{nM}$ nonylphenol (Fig. 1D). Nominal Lowest observable effect concentrations (nLOEC) were observed for embryos exposed to EE2, and were identical for all three compounds for yolk-sac larvae, feeding fry and smolts (Table 2).

Feeding fry Vtg transcription in whole body (Fig. 1C) was compared with Vtg transcription in liver (Fig. 2) to determine whether patterns of transcription differed significantly. Both whole body and liver only Vtg showed significant upregulation in response to the two highest doses of EE2 and E2, as well as the highest dose of NP. The pattern of response differed between tissue types only with the intermediate dose of NP, where Vtg transcription was elevated in the whole body, but not significantly elevated in the liver. 

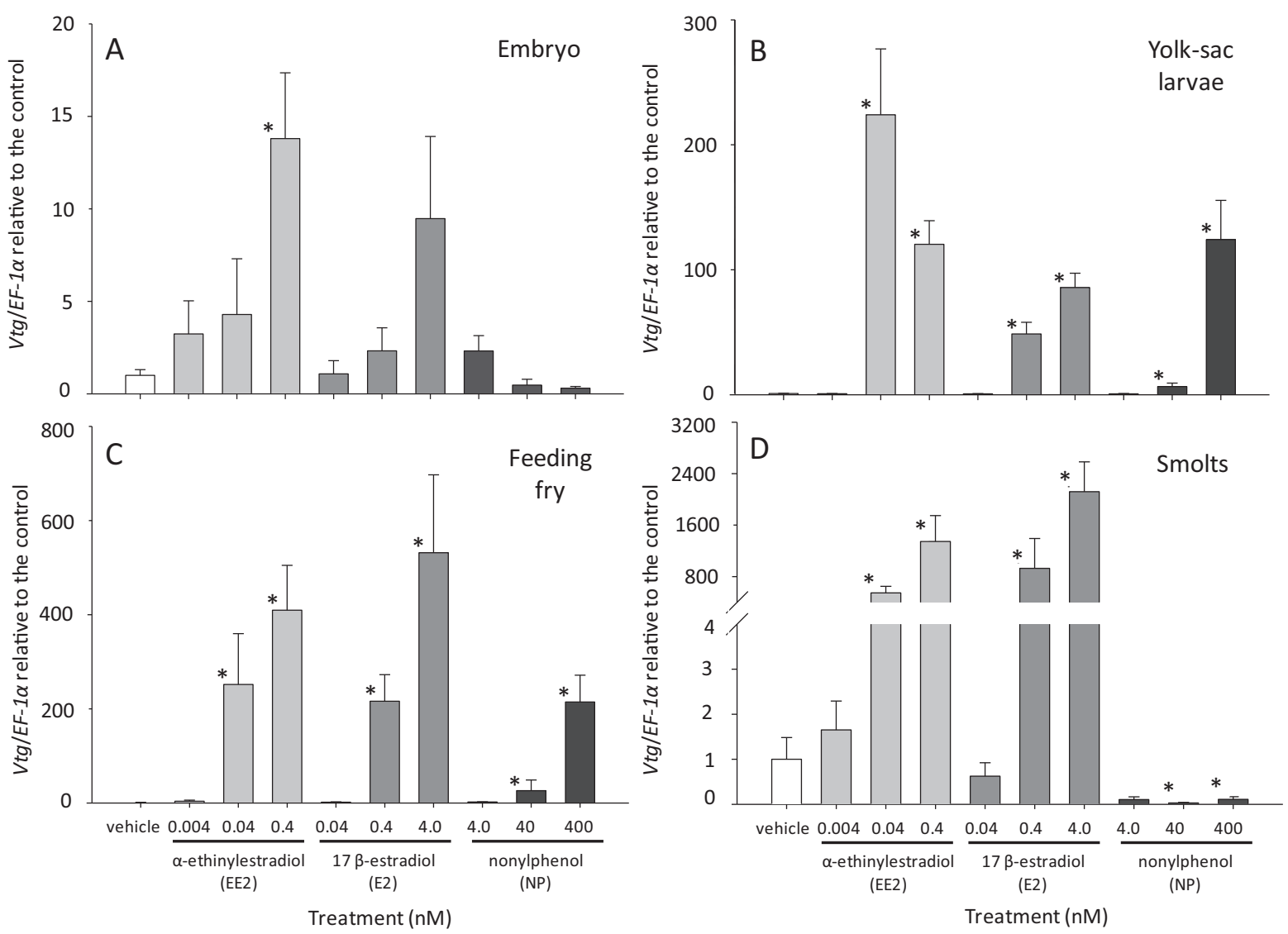

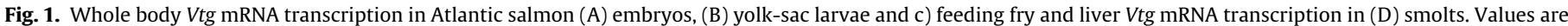

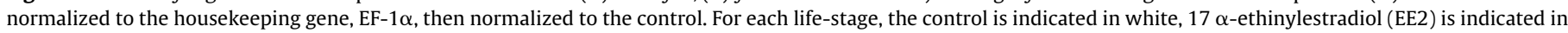

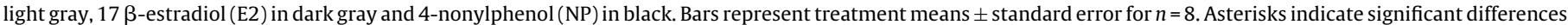
$(p<0.05)$ between each concentration and the control for each life stage.

\subsection{Vtg enzyme immunoassay (EIA)}

Smolt plasma Vtg protein concentration increased in response to all compounds (1-way ANOVA, $p<0.001$ ) and a clear dosedependent response for both $17 \alpha$-ethinylestradiol and 17 $\beta$-estradiol wherein all doses elicited increased Vtg (Fig. 3). Dosedependency was less clear for nonylphenol, but both the 4.0 and $400 \mathrm{nM}$ doses elicited significant increases in plasma Vtg concentration. No differences for Vtg concentration based on sex $(n=4$ females and 4 males per treatment) were found (2-way ANOVA, $p=0.315$ ).

Table 2

Nominal lowest observable effect concentration (nLOEC) for early life stage exposures in Atlantic salmon based on Vtg mRNA upregulation of whole body (embryo, larvae and feeding fry) or liver only (feeding fry and smolts).

\begin{tabular}{llll}
\hline & \multicolumn{2}{l}{ Compound (nominal, $\mu \mathrm{M})$} \\
\cline { 2 - 4 } & $\begin{array}{l}\alpha- \\
\text { Ethinylestradiol } \\
\end{array}$ & $\begin{array}{l}17 \\
(\mathrm{EE} 2)\end{array}$ & $\begin{array}{l}\text { Nonylphenol } \\
(\mathrm{E} 2)\end{array}$ \\
\hline Embryo & $\mathrm{ND}$ & 0.4 & $\mathrm{ND}$ \\
Yolk-sac larvae & 0.4 & 0.04 & 40.0 \\
Feeding fry(whole body) & 0.4 & 0.04 & 40.0 \\
Feeding fry(liver) & 0.4 & 0.04 & 400.0 \\
Smolts(liver) & 0.04 & 0.4 & 40.0 \\
\hline
\end{tabular}

ND, not determined.

\subsection{Additional physiological parameters}

In smolts, hepatosomatic index (HSI) was significantly elevated in response to the highest doses of $17 \alpha$-ethinylestradiol and 17 $\beta$-estradiol, but no significant differences were noted for nonylphenol (Fig. 4). Additionally, plasma $\mathrm{T}_{4}$ and cortisol levels did not vary among treatments (Table 3 ) and plasma $\mathrm{T}_{3}$ levels were significantly reduced by exposure to $17 \alpha$-ethinylestradiol.

Gill $\mathrm{Na}^{+} / \mathrm{K}^{+}$-ATPase (hereafter, NKA) activity was measured in smolt gill tissue to determine potential effects of EDC exposure on seawater tolerance. Controls from each set of exposures differed significantly, with nonylphenol control NKA activity being significantly lower than control NKA values for $17 \alpha$-ethinylestradiol. Within a given experiment (all doses of a single compound) no significant differences in NKA were noted among concentrations. Therefore, NKA activity did not exhibit compound- or dose-dependent response.

\section{Discussion}

Atlantic salmon demonstrated robust physiological responses to three estrogenic compounds commonly found in wastewater effluent and urbanized river systems and estuaries. In this study, $V t g$ served as a biomarker of response during 4-day exposures to varying concentrations of these compounds. All life stages clearly responded to aqueous exposure, but sensitivity (lowest dose of response) and the magnitude of response appeared to be life stage-, compound-and dose-dependent. The estrogens, E2 and EE2 elicited 
Table 3

Physiological and endocrine changes in smolts in response to EDC exposure. All values are mean $\pm \mathrm{SE}$ for $n=8$.

\begin{tabular}{|c|c|c|c|c|c|}
\hline & & $\begin{array}{l}\alpha \text {-Ethinylestradiol } \\
(\text { EE2) }\end{array}$ & $\begin{array}{l}\text { Compound } 17 \beta-e_{3} \text { tradiol } \\
\text { (E2) }\end{array}$ & $\begin{array}{l}\text { Nonylphenol } \\
(\mathrm{NP})\end{array}$ & Statistical test and significance level \\
\hline \multirow[t]{4}{*}{$\mathrm{T}_{4}(\mathrm{ng} / \mathrm{ml})$} & Control & $6.2 \pm 0.7$ & $4.1 \pm 0.1$ & $3.7 \pm 0.5$ & One-way ANOVA \\
\hline & Low & $3.6 \pm 0.2$ & $4.9 \pm 0.2$ & $2.3 \pm 0.1$ & $\mathrm{EE} 2, p=0.44$ \\
\hline & Medium & $3.5 \pm 0.2$ & $5.4 \pm 0.2$ & $3.1 \pm 0.3$ & $\mathrm{E} 2, p=0.81$ \\
\hline & High & $3.2 \pm 0.2$ & $5.2 \pm 0.4$ & $2.5 \pm 0.1$ & $\mathrm{NP}, p=0.18$ \\
\hline \multirow[t]{4}{*}{$\mathrm{T}_{3}(\mathrm{ng} / \mathrm{ml})$} & Control & $2.4 \pm 0.3$ & $2.4 \pm 0.1$ & $2.7 \pm 0.3$ & one-way ANOVA \\
\hline & Low & $2.1 \pm 0.1$ & $2.5 \pm 0.3$ & $2.7 \pm 0.2$ & $\mathrm{EE} 2, p=0.004$ \\
\hline & Medium & $2.3 \pm 0.2$ & $2.6 \pm 0.3$ & $2.7 \pm 0.3$ & $\mathrm{E} 2, p=0.35$ \\
\hline & High & $\mathbf{1 . 6} \pm \mathbf{0 . 1}^{\mathrm{a}}$ & $2.0 \pm 0.2$ & $2.8 \pm 0.2$ & $\mathrm{NP}, p=0.36$ \\
\hline \multirow[t]{4}{*}{ Cortisol (ng/ml) } & Control & $4.4 \pm 1.0$ & $4.2 \pm 1.6$ & $24.1 \pm 12.5$ & One-way ANOVA on ranks \\
\hline & Low & $31.6 \pm 10.6$ & $20.7 \pm 7.2$ & $20.3 \pm 7.6$ & $\mathrm{EE} 2, p=0.16$ \\
\hline & Medium & $7.4 \pm 2.9$ & $14.3 \pm 6.9$ & $22.5 \pm 8.6$ & $\mathrm{E} 2, p=0.43$ \\
\hline & High & $10.1 \pm 1.7$ & $15.8 \pm 4.7$ & $14.6 \pm 4.5$ & $\mathrm{NP}, p=0.89$ \\
\hline \multirow[t]{4}{*}{$\mathrm{Na}^{+} / \mathrm{K}^{+}$-ATPase $(\mathrm{ng} / \mathrm{ml})$} & Control & $4.6 \pm 0.4$ & $5.8 \pm 0.4$ & $4.2 \pm 0.3$ & One-way ANOVA \\
\hline & Low & $4.3 \pm 0.4$ & $5.6 \pm 0.4$ & $4.2 \pm 0.4$ & $\mathrm{EE} 2, p=0.73$ \\
\hline & Medium & $4.3 \pm 0.4$ & $5.5 \pm 0.6$ & $4.7 \pm 0.5$ & $\mathrm{E} 2, p=0.97$ \\
\hline & High & $4.0 \pm 0.3$ & $5.7 \pm 0.5$ & $4.5 \pm 0.4$ & $\mathrm{NP}, p=0.67$ \\
\hline
\end{tabular}

Significant treatment effects are indicated in the right-hand column in bold.

a Significantly different from the control in post hoc comparisons. Highlighted 'control' row indicates significant differences among controls (see text for details).

the strongest overall Vtg response, while response to NP was muted. Clearly, each life stage was capable of a vitellogenic response that was partially dose-dependent, but the dose that elicited this response and the corresponding magnitude of response varied among life stages.

Relative estrogenicity was compared among treatments using EEQs obtained from a BLYES assay (Sanseverino et al., 2005). Because the BLYES assay is based on a response equivalent to $17 \beta$-estradiol, the E2 treatments were most closely comparable between the nominal E2 concentrations and the corresponding EEQs. The E2 treatments demonstrated logarithmic EEQ values that were consistent with the nominal concentrations (Table 1). However, EEQ values for E2 were approximately 33\% less than would be expected based on the nominal concentrations, indicating that actual E2 concentrations were likely 33\% of nominal concentrations. EE2 demonstrated similar EEQ values for the low and medium doses, but the highest dose was considerably lower than expected, despite significant responses in Vtg in response to the high dose of

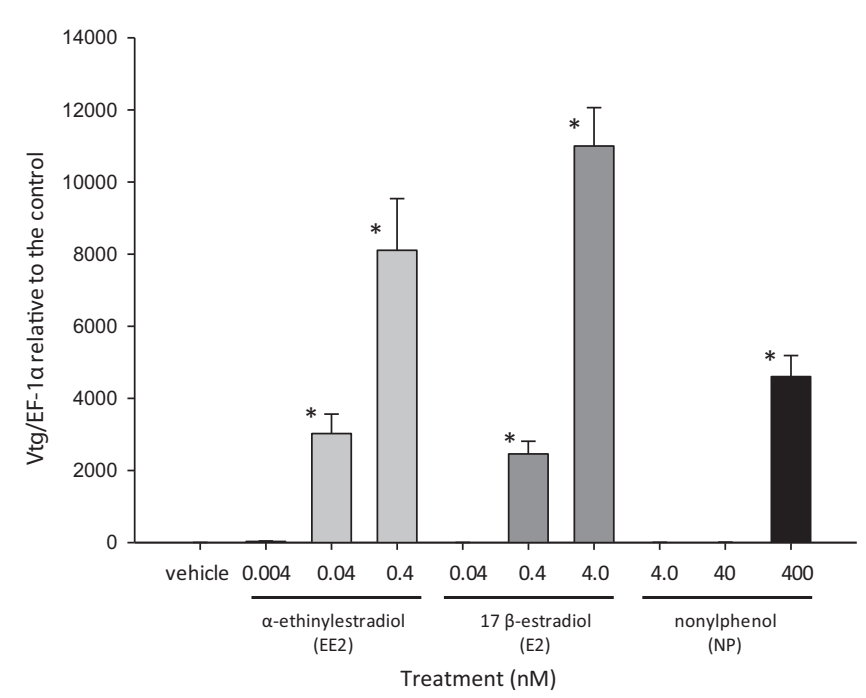

Fig. 2. Liver Vtg mRNA levels in Atlantic feeding fry exposed to endocrine disrupting compounds. Values are normalized to the housekeeping gene, EF- $1 \alpha$, and then normalized to the control. The control is indicated in white, $17 \alpha$-ethinylestradiol (EE2) is indicated in light gray, $17 \beta$-estradiol (E2) in dark gray and 4-nonylphenol (NP) in black. Bars represent treatment means \pm standard error for $n=8$. Asterisks indicate significant differences between each concentration and the control.
EE2. Lower than anticipated EEQ values may be due to loss of EE2 from the water column by organism uptake, bacterial degradation, or compound adsorption to tank walls, organic material (i.e. feces) and/or polystyrene collection tubes (Cajthaml et al., 2009). Given the robust $V t g$ response in all life stages, it is likely that organism uptake played a role in removing compounds from the water column. EE2 is generally more stable than natural estrogens, but due to high hydrophobicity, adsorption may have been a primary factor in removing a large portion of the EE2 from the highest concentration.

Nonylphenol showed weak to no estrogenic activity in the BLYES assay, with the highest dose of NP resulting in an EEQ value that was comparable to the low dose EEQ values of EE2 and E2. Both the low and medium doses of NP were below the detection limit. Nonylphenol demonstrates a weak affinity for the estrogen receptor family and is generally considered to be a weakly estrogenic member of the alkylphenol group (Shanle and Xu, 2011). For example, nonylphenol was 120,000 -fold less estrogenic than $17 \beta$-estradiol when measured in an estrogen receptor binding assay (Lee et al., 2012) and the concentration to induce luciferase activity via the estrogen

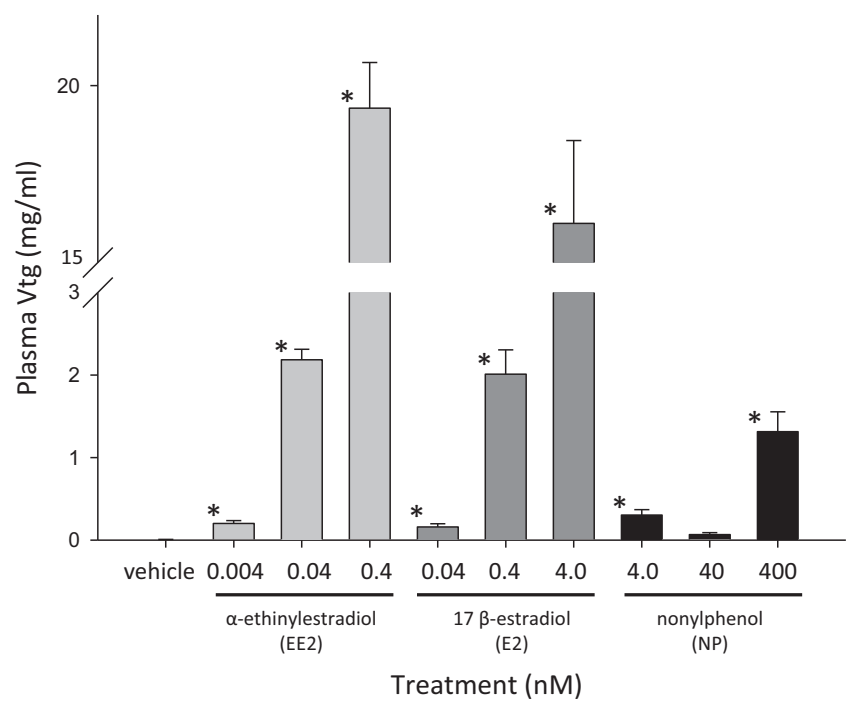

Fig. 3. Plasma Vtg protein concentration in Atlantic salmon smolts exposed to endocrine disrupting compounds. The control is indicated in white, $17 \alpha$ ethinylestradiol (EE2) is indicated in light gray, $17 \beta$-estradiol (E2) in dark gray and 4-nonylphenol (NP) in black. Bars represent treatment means \pm standard error for $n=4$ males and 4 females. Asterisks indicate significant differences between each concentration and the control. 


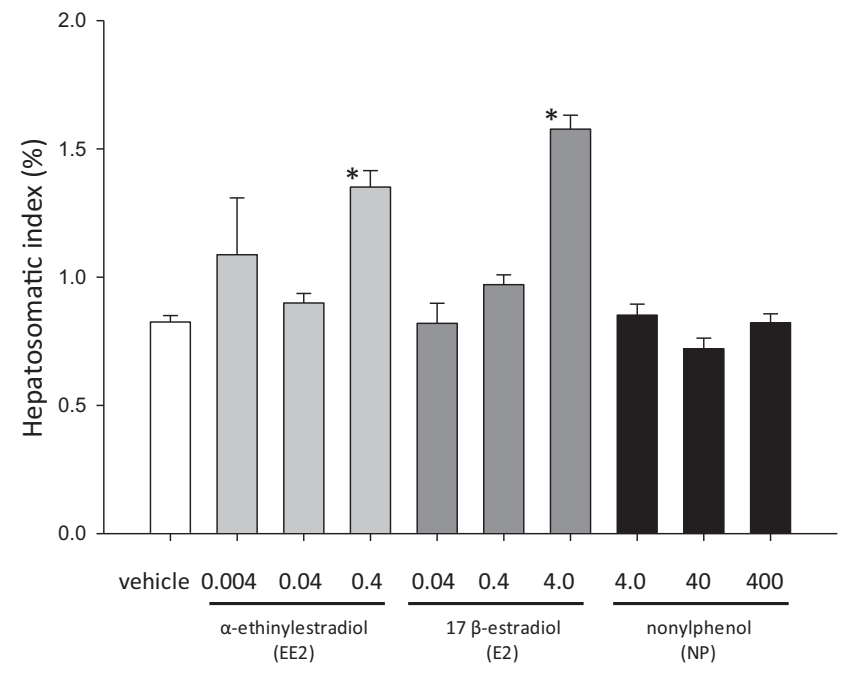

Fig. 4. Hepatosomatic index for Atlantic salmon smolts exposed to endocrine disrupting compounds. Bars represent treatment means \pm standard error for $n=8$. Asterisks indicate significant differences between each concentration and the control for each compound.

receptors in a transfected lactoferrin reporter assay was 1000 times greater than the concentration of $17 \beta$-estradiol (Ranhotra and Teng, 2005). In the BLYES assay, the $\mathrm{EC}_{50}[\mathrm{M}]$ for para-nonylphenol was $1.7 \times 10^{-5}$ (Sanseverino et al., 2005), which is approximately the same order of magnitude as the highest concentration for 4nonylphenol used in this study. Sanseverino et al. (2005) used para-nonylphenol, while in the present study 4-nonylphenol was used, which is generally thought to change the estrogenicity based on isomer content and physical structure (Lalah et al., 2007).

In this study, none of the tested compounds resulted in detectable mortality during the $96-\mathrm{h}$ exposure period. Many tests for compound or effluent toxicity focus on $\mathrm{LD}_{50}$, the dose or dilution at which 50\% mortality occurs (Chapman, 2000). This measure of mortality often overlooks sublethal effects that can alter longterm behavior, disease susceptibility and overall fitness. Lerner et al. (2007b) details an example of sublethal impacts on Atlantic salmon. Yolk-sac larvae exposed to E2 and NP for 21 days had minimal mortality during exposure to E2 and the lowest dose of NP, whereas the high dose of NP elicited mortality during the exposure period (21 days). However, all EDC treatments resulted in significant cumulative mortality by 60 days after the exposures were ended and the fish had reduced ability to increase gill $\mathrm{Na}^{+} / \mathrm{K}^{+}$ATPase activity during smolt development, indicating a decreased capacity for seawater survival. Other studies have linked estrogenic compounds to reduced salinity tolerance and performance during smolting (McCormick et al., 2005; Bangsgaard et al., 2006), demonstrating long-lasting, sublethal effects that result in morbidity and mortality later in life.

Vitellogenin is a common biomarker of EDC exposure that may be indicative of potential sublethal impacts (Jones et al., 2000). In this study, Vtg was used to compare responsiveness among fish of different life stages, as this could suggest the potential for differential susceptibility to endocrine disruption among life stages. $V t g$ transcription (whole animal or liver) was used to compare the nominal Lowest Observable Effect Concentration (LOEC, nominal concentrations) across life stages. The liver is the primary site of $V t g$ transcription and protein production (Mommsen and Walsh, 1988), and in this study we assumed that the Vtg mRNA signal in whole animals resulted primarily from transcription in the liver. The comparison between feeding fry Vtg in liver and whole bodies demonstrated that the overall patterns of responsiveness to the three compounds were similar, with the one exception of a difference in NP responsiveness between liver and whole body for the $40 \mathrm{nM}$ dose. It is interesting to note that fold-change in transcription for the $40 \mathrm{nM}$ dose for both the whole body and liver show similar ranges $(0.4-10.7, n=8$ and $1.9-15.6, n=8$, respectively), with the exception of a single individual with a 185 -fold increase in whole body Vtg mRNA levels that is driving this difference. This suggests there is significant individual variation in these early life-stages during early development of estrogen signaling, and that this variability may be pronounced when the estrogenic signal is weak, as may be the case with NP (Shanle and Xu, 2011). The comparison between Vtg transcription in fry liver and whole bodies demonstrates that while the overall pattern is similar, the magnitude of fold-change in transcription differs by 10 - to 20 fold between liver and whole body responses with liver having the higher maximal transcription. This is likely to be a reflection of 'RNA swamping', where the mRNA signal from liver is high, but is diluted in whole-body RNA extracts due to the inclusion of other, non-Vtg encoding mRNA from other tissue types (Mommsen and Walsh, 1988). However, these data suggest that comparisons of Vtg patterns from whole body and liver extracts are similar at least with regard to dose dependency and minimum effective doses.

Embryos displayed reduced and more variable Vtg mRNA response relative to the yolk-sac larvae and feeding fry. Embryo $V t g$ was upregulated in response to the highest dose of EE2 (nLOEC at $0.4 \mathrm{nM}$ ) and no dose of either E2 or NP elicited a statistically significant response (nLOEC not determined), despite some variability in $V t g$ response This variability in $V t g$ transcription within single a treatment suggests that embryos are undergoing a developmental transition that increases responsiveness during this life stage, despite an overall non-significant response, and that the variability in response may be due to small changes in developmental stages among embryos. The comparison of variability in transcription between embryos and older life stages may be driven by differences in experimental temperature $\left(7^{\circ} \mathrm{C}\right.$ for embryos, $15^{\circ} \mathrm{C}$ for all other life stages). Low temperatures in the embryonic stages may have suppressed Vtg transcription relative to embryos that were reared at $15^{\circ} \mathrm{C}$, but $S$. salar embryos reared above $\sim 11^{\circ} \mathrm{C}$ demonstrate reduced hatch rate and developmental deformities (Poxton, 1991). It is important to note that these treatments were carried out within the environmentally relevant temperature range for each life-stage (Poxton, 1991) and therefore are representative of responses in the wild. Whole animal Vtg mRNA was clearly upregulated in yolksac larvae and feeding fry exposed to EE2 (several hundred times the number of control transcripts and 10- to 60-fold greater transcription levels than in EE2-responsive embryos). Taken together, high variability in responsiveness within treatments in embryos and increasing maximal responsiveness in progressive life stages suggest a developmental progression in estrogen signaling that is occurring in late-stage embryos and/or newly hatched larvae. To determine the timing of responsiveness in the Vtg gene, it would be necessary to assess multiple timepoints in embryonic development, given the protracted nature of Atlantic salmon embryonic development (Poxton, 1991). Stage of exposure is an important consideration for biomarker assays with Atlantic salmon, and possibly other teleost early life stages.

One plausible explanation for these life-stage differences in Vtg may be due to a developmental increase in estrogen receptormediated $V t g$ induction. The impacts of the endogenously regulated natural estrogen, $17 \beta$-estradiol are mediated by at least three known estrogen receptor (ER) subtypes in teleosts, ER $\alpha, E R \beta 1$ and ER $\beta 2$ (Katsu et al., 2013; Nelson and Habibi, 2013), but a fourth isoform $(E R \alpha 2)$ has been found in a related species, rainbow trout (Nagler et al., 2007). Regulation of circulating E2 by ERs is an important regulator of ovarian development in fish and is interlinked with growth and development (Devlin and Nagahama, 2002). Estrogen receptors increase in number during development, 
and in particular are likely to increase rapidly prior to and during sexual differentiation and reproduction (Liao et al., 2009), and transcription of different isoforms shifts periodically throughout early development (Chandrasekar et al., 2010). Gonad differentiation begins early in development in Atlantic salmon, as many of the major genes involved in sex determination and differentiation are upregulated in the embryonic stage (von Schalburg et al., 2011). Gonad development is plastic throughout early development, and exposure to aqueous and dietary EDCs can skew sex ratios (Davidson et al., 2009; Norrgren et al., 1999) by binding to the estrogen receptor(s) (Kloas et al., 2000; Scholz et al., 2013). Exposure to estrogenic compounds in the wild during early development could have profound effects on population dynamics and recruitment success of Atlantic salmon by affecting sex ratios and reproductive development.

Salmon smolts were also clearly sensitive to each compound, with liver Vtg mRNA upregulated in a dose-dependent manner, and a nominal LOEC at the intermediate dose for each compound (Fig. 2). Plasma Vtg was significantly increased in response to the lowest dose of each compound, but this was not mirrored by Vtg mRNA levels. One possible explanation for this discrepancy between mRNA and protein responses is that Vtg mRNA was upregulated early in the exposure period, and by day four Vtg mRNA transcription had decreased from previous levels in the lowest concentration exposures. Further, the low and medium dose of NP exhibit downregulation of $V t g$ mRNA, providing further support for potential downregulation of Vtg. Vitellogenin transcription is transient, and temporal lags between Vtg mRNA transcription and Vtg protein concentration in the plasma have been documented (Bowman et al., 2000; Korte et al., 2000). Vitellogenin protein concentration is clearly the more sensitive measure of EDC exposure for smolts in the present study, and our results our supported by reports of elevated Vtg that is often present in the plasma for days to weeks following exposure (Korte et al., 2000). Here, we have developed and validated a very sensitive EIA for the detection of low concentrations of Atlantic salmon Vtg, and this technique could be used as a non-lethal biomarker of EDC exposure in wild fish. We argue that in certain cases, this immunochemical approach may be more sensitive for determining exposure to estrogenic compounds than a molecular-based approach.

Vitellogenin is used as a biomarker of EDC exposure in both laboratory experiments and in wildlife (Bernanke and Koehler, 2009). Elevated Vtg outside of the normal period of reproduction is strongly associated with negative impacts to fitness such as depressed growth (Leet et al., 2011), altered gonad morphology and function (Tyler and Routledge, 1998; Tyler and Jobling, 2008), and reproductive success (Mills et al., 2003). In some cases, the accumulation of Vtg in circulation can impair liver function and lead to pathological changes in the liver, kidney and testes (Folmar et al., 2001; Palace et al., 2002). Effects of EDCs on Vtg may be ephemeral or persist for more than 4 days (Tyler et al., 1998; Leet et al., 2011). If spawning occurs in areas where EDCs are ubiquitous, exposure may span weeks to months during early development, potentially inducing a much greater Vtg response than the one demonstrated here. Smolts may likely see a similar, short-term exposure to these compounds from wastewater effluent as they migrate though urbanized areas. However, in an impacted river with multiple wastewater dischargers, smolts may potentially experience high concentrations of EDCs throughout their migratory journey.

Other measures of physiological status were also impacted by EDC exposure. Hepatosomatic index was clearly elevated in smolts exposed to high concentrations of EE2 and E2, presumably due to the increase in both hepatocyte size and number stemming from increased Vtg synthesis and clearance of byproducts of contaminant metabolism (Leet et al., 2011). Increased HSI is a typical response to endogenous estrogens as well as endocrine disruptor exposure (Keen et al., 2005; Lerner et al., 2012). HSI is often elevated naturally during reproduction as a result of increased protein synthesis and Vtg production and may be reflective of increased Vtg production in the present study. The thyroid hormones (thyroxine, $\mathrm{T}_{4}$ and triiodothyronine, $\mathrm{T}_{3}$ ) are important indirect regulators of growth, smolt development and salinity tolerance in Atlantic salmon (McCormick, 2001; Stefansson et al., 2012), but regulation of these hormones is often disrupted in response to estrogenic compounds (Keen et al., 2005; Lerner et al., 2007a). Smolting generally results in an increase in circulating $\mathrm{T}_{4}$ and $\mathrm{T}_{3}$ levels (Stefansson et al., 2012), but reductions in $\mathrm{T}_{3}$ have been documented for exposure to compounds during smolting (McCormick et al., 2005; Lerner et al., 2007a). In this study, $\mathrm{T}_{3}$ was significantly reduced in fish exposed to the highest dose of EE2, but no significant changes to $\mathrm{T}_{4}$ were observed. This is consistent with results from aqueous exposure to EDCs (Lerner et al., 2007a) as well as dietary exposure (Keen et al., 2005) in salmonids. Reductions in $T_{3}$ may contribute to reduced osmoregulatory performance in animals, but this likely requires changes to other hormonal processes involved in smolting. The parr-smolt transformation is controlled by multiple factors including the thyroid hormones, cortisol and the growth hormoneinsulin-like growth factor axis. Increased circulating levels of these hormones during smolting results in increased gill NKA activity and hypo-osmoregulatory function (McCormick, 1994). In the present study, we saw no change in $\mathrm{Na}^{+} / \mathrm{K}^{+}$-ATPase activity with exposure to estrogenic compound. Previous studies have demonstrated reduced ability to regulate the mechanisms necessary for seawater entry following prolonged exposure to EDCs during an earlier life stage (Bangsgaard et al., 2006; Lerner et al., 2007a,b). Cortisol is well documented to influence NKA activity, and in the present study, no changes in circulating cortisol were observed among treatments. Together, these potential indicators of smolt impairment do not indicate reduced ionoregulatory ability following 4-day exposure to the compounds and concentrations used in the present study. Previous studies have shown greater loss of gill NKA and salinity tolerance with length of exposure (McCormick et al., 2005), so it is likely that acute, 96-h exposures were not long enough to induce significant changes in these indicators of osmoregulatory capability.

This work demonstrates clear differences among life-stage in responsiveness to three common EDCs, as measured by Vtg transcription. We also found that circulating levels of Vtg were more sensitive indicators of EDC exposure than was Vtg transcription. Additionally, exposure to these compounds elicits some alterations to physiological measures of osmoregulatory function in salmon undergoing smoltification. Vtg responsiveness is likely to be an indicator of which life stage may be responsive to environmental endocrine disruptors, but further work will be necessary to determine which stages are most sensitive to long term impacts on growth and reproduction. Understanding life stage sensitivity may be an important component of conservation of Atlantic salmon in watersheds where endocrine disrupting chemicals are prevalent.

\section{Contributions}

T. Duffy, S. McCormick and L. Iwanowicz each participated in the research and manuscript preparation and revision. All authors have approved the final submission.

\section{Acknowledgments}

The authors would like to thank M. O'Dea for fish care, A. Regish and A. Christensen for help in validating the EIA assay, M. Nichols and A. Sperry with help in water sample extractions, J. Breves for 
qPCR analysis, and K. Peck for sharing the EIA protocol. We thank A. Elskus for her helpful comments during manuscript revisions and two anonymous reviewers for their comments. We also thank White River National Fish Hatchery for generously donating early life stage salmon for this work, and the Kensington Atlantic State Fishing Hatchery for donation of smolts. Additionally, we thank J. Sanseverino of the Center for Environmental Biotechnology, University of Tennessee (Knoxville, TN) for kindly providing strain BLYES. This research was funded by NOAA-grant EA133F10NC2729 and a USGS Mendenhall Fellowship to T. Duffy. This research was partially funded by the USGS Fisheries and Contaminants Programs to L. Iwanowicz and S.D. McCormick. Any use of trade, product, or firm names is for descriptive purposes only and does not imply endorsement by the US Government.

\section{References}

Arukwe, A, Roe, K, 2008. Molecular and cellular detection of expression of vitellogenin and zona radiata protein in liver and skin of juvenile salmon (Salmo salar) exposed to nonylphenol. Cell Tissue Res. 331, 701-712.

Bangsgaard, K., Madsen, S.S., Korsgaard, B., 2006. Effect of waterborne exposure to 4-tert-octylphenol and 17 beta-estradiol on smoltification and downstream migration in Atlantic salmon, Salmo salar. Aquat. Toxicol. 80, 23-32.

Bernanke, J., Koehler, H.-R., 2009. The Impact of Environmental Chemicals on Wildlife Vertebrates. In: Whitacre, D.M. (Ed.), Reviews of Environmental Contamination and Toxicology, 198. Springer, New York, pp. 1-47.

Blazer, V.S., Iwanowicz, L.R., Henderson, H., Mazik, P.M., Jenkins, J.A., Alvarez, D.A., Young, J.A., 2012. Reproductive endocrine disruption in smallmouth bass (Micropterus dolomieu) in the Potomac River basin: spatial and temporal comparisons of biological effects. Environ. Monit. Assess. 184, 4309-4334

Blazer, V.S., Iwanowicz, L.R., Iwanowicz, D.D., Smith, D.R., Young, J.A., Hedrick, J.D. Foster, S.W., Reeser, S.J., 2007. Intersex (testicular oocytes) in smallmouth bas from the Potomac River and selected nearby drainages. J. Aquat. Anim. Health $19,242-253$

Bowman, C.J., Kroll, K.J., Hemmer, M.J., Folmar, L.C., Denslow, N.D., 2000. Estrogeninduced vitellogenin mRNA and protein in sheepshead minnow (Cyprinodon variegatus). Gen. Comp. Endocriol. 120, 300-313.

Brion, F., Tyler, C.R., Palazzi, X., Laillet, B., Porcher, J.M., Garric, J., Flammarion, P. 2004. Impacts of 17 beta-estradiol, including environmentally relevant concentrations, on reproduction after exposure during embryo-larval-, juvenile- and adult-life stages in zebrafish (Danio rerio). Aquat. Toxicol. 68, 193-217.

Cajthaml, T., Krsinova, Z., Svobodova, K., Sigler, K., Rezanka, T., 2009. Microbial transformation of synthetic estrogen 17a-ethinylestradiol. Environ. Pollut. 157, 3325-3335.

Carey, J.B., McCormick, S.D., 1998. Atlantic salmon smolts are more responsive to handling and confinement stress than parr. Aquaculture 168, 237-253.

Chandrasekar, G., Archer, A., Gustafsson, J.-A., Andersson Lendahl, M., 2010. Levels of 17 b-estradiol receptors expressed in embryonic and adult zebrafish following in vivo treatment of natural or synthetic ligands. PLoS ONE 5, e9678, http://dx.doi.org/10.1371/journal.pone.0009678.

Chapman, P.M., 2000. Whole effluent toxicity testing - usefulness, level of protec tion, and risk assessment. Environ. Toxicol. Chem. 19, 3-13.

Ciparis, S., Iwanowicz, L.R., Voshell, J.R., 2012. Effects of watershed densities of animal feeding operations on nutrient concentrations and estrogenic activity in agricultural streams. Sci. Total Environ. 414, 268-276.

Davidson, W.S., Huang, T.-K., Fujiki, K., von Schalburg, K.R., Koop, B.F., 2009. The sex determining loci and sex chromosomes in the family Salmonidae. Sex. Dev. 3, $78-87$

Desbrow, C., Routledge, E.J., Brighty, G.C., Sumpter, J.P., Waldock, M., 1998. Identification of estrogenic chemicals in STW effluent 1. Chemical fractionation and in vitro biological screening. Environ. Sci. Technol. 32, 1549-1558.

Devlin, R.H., Nagahama, Y., 2002. Sex determination and sex differentiation in fish: an overview of genetic, physiological, and environmental influences. Aquaculture 208, 191-364.

Dickhoff, W.W., Folmar, L.C., Gorbman, A., 1979. Plasma thyroid-hormones in 6 species of Salmonidae. Am. Zool. 19, 937

Fairchild, W.L., Swansburg, E.O., Arsenault, J.T., Brown, S.B., 1999. Does an association between pesticide use and subsequent declines in catch of Atlantic salmon (Salmo salar) represent a case of endocrine disruption? Environ. Health Perspect. $107,349-358$.

Folmar, L.C., Gardner, G.R., Schreibman, M.P., Magliulo-Cepriano, L., Mills, L.J. Zaroogian, G., Gutjahr-Gobell, R., Haebler, R., Horowitz, D.B., Denslow, N.D., 2001. Vitellogenin-induced pathology in male summer flounder (Paralichthys dentatus). Aquat. Toxicol. 51, 431-441.

Ingerslev, H.C., Cunningham, C., Wergeland, H.I., 2006. Cloning and expression of TNF-alpha IL-1 beta and COX-2 in an anadromous and landlocked strain of Atlantic salmon (Salmo salar L.) during the smolting period. Fish Shellfish Immunol. 20, 450-461.

Johnson, A.C., Sumpter, J.P., 2001. Removal of endocrine-disrupting chemicals in activated sludge treatment works. Environ. Sci. Technol. 35, 4697-4703.
Jones, P.D., Tremblay, L.A., De Coen, W.M., Giesy, J.P., 2000. Vitellogenin as a biomarker for environmental estrogens. Australas. J. Ecotoxicol. 6, 45-58.

Kaptaner, B., Kankaya, E., Unal, G., 2009. Effects of 17 alpha-ethinylestradiol on hepatosomatic index, plasma vitellogenin levels and liver glutathione-s-transferase activity in Lake Van fish (Chalcalburnus tarichi Pallas, 1811). Fresenius Environ. Bull. 18, 2366-2372

Katsu, Y., Lange, A., Miyagawa, S., Urushitani, H., Tatarazako, N., Kawashima, Y. Tyler, C.R., Iguchi, T., 2013. Cloning, expression and functional characterization of carp, Cyprinus carpio, estrogen receptors and their differential activations by estrogens. J. Appl. Toxicol. 33, 41-49.

Keen, P.L., Higgs, D.A., Hall, K.J., Ikonomou, M., 2005. Effects of dietary exposure of 4-nonylphenol on growth and smoltification of juvenile coho salmon (Oncorhynchus kisutch). Sci. Total Environ. 349, 81-94.

Kidd, K.A., Blanchfield, P.J., Mills, K.H., Palace, V.P., Evans, R.E., Lazorchak, J.M., Flick, R.W., 2007. Collapse of a fish population after exposure to a synthetic estrogen. Proc. Natl. Acad. Sci. U.S.A. 104, 8897-8901.

Kloas, W., Schrag, B., Ehnes, C., Segner, H., 2000. Binding of xenobiotics to hepatic estrogen receptor and plasma sex steroid binding protein in the teleost fish, the common carp (Cyprinus carpio). Gen. Comp. Endocrinol. 119, 287-299.

Koger, C.S., Teh, S.J., Hinton, D.E., 2000. Determining the sensitive developmenta stages of intersex induction in medaka (Oryzias latipes) exposed to 17 betaestradiol or testosterone. Mar. Environ. Res. 50, 201-206.

Korte, J.J., Kahl, M.D., Jensen, K.M., Pasha, M.S., Parks, L.G., LeBlanc, G.A., Ankley, G.T., 2000. Fathead minnow vitellogenin: complementary DNA sequence and messenger RNA and protein expression after 17 beta-estradiol treatment. Environ. Toxicol. Chem. 19, 972-981.

Lagana, A., Faberi, A., Fago, G., De Leva, I., Faberi, A., Fago, G., Marino, A. 2004. Application of an innovative matrix solid-phase dispersion-solidphase extraction-liquid chromatography-tandem mass spectrometry analytica methodology to the study of the metabolism of the estrogenic mycotoxin zearalenone in rainbow trout liver and muscular tissue. Int. J. Environ Anal. Chem. 84, 1009-1016.

Lalah,J.O., Severin, G.F., Schramm, K.W., Lenoir, D., Behechti, A., Guenther, K., Kettrup, A., 2007. Effects of a branched p-nonylphenol isomer (4(3',6'-dimethyl-3'heptyl)-phenol) on embryogenesis in Lymnae stagnalis L. Arch. Environ. Contam. Toxicol. 52, 104-112.

Lange, A., Paull, G.C., Hamilton, P.B., Iguchi, T., Tyler, C.R., 2011. Implications of persistent exposure to treated wastewater effluent for breeding in wild roach (Rutilus rutilus) populations. Environ. Sci. Technol. 45, 1673-1679.

Lee, K.L., Kim, T.S., Kim, C.Y., Kang, H.I., Kim, M.G., Jung, K.K., Kim, H.S., Han, S.Y., Yoon, H.J., Rhee, G.S., 2012. Evaluation of in vitro screening system for estrogenicity: comparison of stably transfected human estrogen receptor- $\alpha$ transcriptiona activation (OECD TG455) assay and estrogen receptor (ER) binding assay. J. Toxicol. Sci. 37, 431-437.

Leet, J.K., Gall, H.E., Sepulveda, M.S., 2011. A review of studies on androgen and estrogen exposure in fish early life stages: effects on gene and hormonal control of sexual differentiation. J. Appl. Toxicol. 31, 379-398.

Lerner, D.T., Bjornsson, B.T., McCormick, S.D., 2007a. Aqueous exposure to 4 nonylphenol and 17 beta-estradiol increases stress sensitivity and disrupts ion regulatory ability of juvenile Atlantic salmon. Environ. Toxicol. Chem. 26, 1433-1440.

Lerner, D.T., Bjornsson, B.T., McCormick, S.D., 2007b. Larval exposure to 4nonylphenol and 17 beta-estradiol affects physiological and behaviora development of seawater adaptation in atlantic salmon smolts. Environ. Sci. Technol. 41, 4479-4485

Lerner, D.T., Sheridan, M.A., McCormick, S.D., 2012. Estrogenic compounds decrease growth hormone receptor abundance and alter osmoregulation in Atlantic salmon. Gen. Comp. Endocrinol. 179, 196-204.

Liao, T., Guo, Q.L., Jin, S.W., Cheng, W., Xu, Y., 2009. Comparative responses in rare minnow exposed to 17 beta-estradiol during different life stages. Fish Physiol. Biochem. 35, 341-349.

Liney, K.E., Jobling, S., Shears, J.A., Simpson, P., Tyler, C.R., 2005. Assessing the sensitivity of different life stages for sexual disruption in roach (Rutilus rutilus) exposed to effluents from wastewater treatment works. Environ. Health Perspect. 113, 1299-1307

Lye, C.M., Frid, C.L.J., Gill, M.E., McCormick, D., 1997. Abnormalities in the reproductive health of flounder Platichthys flesus exposed to effluent from a sewage treatment works. Mar. Pollut. Bull. 34, 34-41.

Mao, Z., Zheng, X.F., Zhang, Y.Q., Tao, X.X., Li, Y., Wang, W., 2012. Occurrence and biodegradation of nonylphenol in the environment. Int. J. Mol. Sci. 13, 491-505.

Matthiessen, P., 2003. Endocrine disruption in marine fish. Pure Appl. Chem. 75 2249-2261

McCormick, S.D., 1993. Methods for nonlethal gill biopsy and measurement of $\mathrm{Na}+$ K+-ATPase activity. Can. J. Fish. Aquat. Sci. 50, 656-658.

McCormick, S.D., 1994. Ontogeny and evolution of salinity tolerance in anadromous salmonids-hormones and heterochrony. Estuaries 17, 26-33.

McCormick, S.D., 2001. Endocrine control of osmoregulation in teleost fish. Am. Zool 41, 781-794.

McCormick, S.D., Bjornsson, B.T., Sheridan, M., Eilertson, C., Carey, J.B., Odea, M. 1995. Increased day length stimulates plasma growth-hormone and gill NA+ $\mathrm{K}+-$ ATPase in Atlatnic salmon (Salmo-salar). J. Comp. Physiol. B Biochem. Syst. Environ. Physiol. 165, 245-254.

McCormick, S.D., O’Dea, M.F., Moeckel, A.M., Lerner, D.T., Bjornsson, B.T., 2005 Endocrine disruption of parr-smolt transformation and seawater tolerance of Atlantic salmon by 4-nonylphenol and 17 beta-estradiol. Gen. Comp. Endocrinol. $142,280-288$ 
Meier, S., Morton, H.C., Nyhammer, G., Grosvik, B.E., Makhotin, V., Geffen, A., Boitsov, S., Kvestad, K.A., Bohne-Kjersem, A., Goksoyr, A., Folkvord, A., Klungsoyr, J., Svardal, A., 2010. Development of Atlantic cod (Gadus morhua) exposed to produced water during early life stages. Effects on embryos, larvae, and juvenile fish. Mar. Environ. Res. 70, 383-394.

Mills, L.J., Chichester, C., 2005. Review of evidence: are endocrine-disrupting chemicals in the aquatic environment impacting fish populations? Sci. Total Environ. $343,1-34$

Mills, L.J., Gutjahr-Gobell, R.E., Horowitz, D.B., Denslow, N.D., Chow, M.C., Zaroogian, G.E., 2003. Relationship between reproductive success and male plasma vitellogenin concentrations in cunner Tautogolabrus adspersus. Environ. Health Perspect. 111, 93-99.

Mommsen, P.T., Walsh, P.L., 1988. Vitellogenesis and oocyte assembly. In: Hoar, W.S., Randall, D.J. (Eds.), Fish Physiology. Academic Press, New York, pp. 347-406.

Nagler, J.J., Cavileer, T., Sullivan, J., Cyr, D.G., Rexroad III, C., 2007. The complete nuclear estrogen receptor family in the rainbow trout: discovery of the novel ER $\alpha 2$ and both ER $\beta$ isoforms. Gene 392, 164-173.

Nelson, E.R., Habibi, H.R., 2013. Estrogen receptor function and regulation in fish and other vertebrates. Gen. Comp. Endocrinol. 192, 15-24.

Norrgren, L., Blom, A., Andersson, P.L., Börjeson, H., Larsson, D.G.J., Olsson, P.-E., 1999. Effects of potential xenoestrogens (DEHP, nonylphenol and PCB) on sexual differentiation in juvenile Atlantic salmon (Salmo salar). Aquat. Ecosyst. Health Manage. 2, 311-317.

Oberdorster, E., Cheek, A.O., 2001. Gender benders at the beach: endocrine disruption in marine and estuarine organisms. Environ. Toxicol. Chem. 20, 23-36

Palace, V.P., Evans, R.E., Wautier, K., Baron, C., Vandenbyllardt, L., Vandersteen, W., Kidd, K., 2002. Induction of vitellogenin and histological effects in wild fathead minnows from a lake experimentally treated with the synthetic estrogen, ethinylestradiol. Water Qual. Res. J. Can. 37, 637-650.

Peck, K.A., Lomax, D.P., Olson, O.P., Sol, S.Y., Swanson, P., Johnson, L.L., 2011. Development of an enzyme-linked immunosorbent assay for quantifying vitellogenin in Pacific salmon and assessment of field exposure to environmental estrogens. Environ. Toxicol. Chem. 30, 477-486.

Poxton, M.G., 1991. Incubation of salmon eggs and rearing of alevins-natural temperature fluctuations and their influence on hatchery requirements. Aquacult. Eng. 10, 31-53.

Ranhotra, H.S., Teng, C.T., 2005. Assessing the estrogenicity of environmental chemicals with a stably transfected lactoferrin gene promoter reporter in HeLa cells. Environ. Toxicol. Pharmacol. 20, 42-47.

Routledge, E.J., Sumpter, J.P., 1996. Estrogenic activity of surfactants and some of their degradation products assessed using a recombinant yeast screen. Environ. Toxicol. Chem. 15, 241-248.
Sanseverino, J., Gupta, R.K., Layton, A.C., Patterson, S.S., Ripp, S.A., Saidak, L., Simpson, M.L., Schultz, T.W., Sayler, G.S., 2005. Use of Saccharomyces cerevisiae BLYES expressing bacterial bioluminescence for rapid, sensitive detection of estrogenic compounds. Appl. Environ. Microbiol. 71, 4455-4460.

Scholz, S., Renner, P., Belanger, S.E., Busquet, F., David, R., Demeneix, B.A., Denny, J.S. Leonard, M., McMaster, M.E., Villeneuve, D.L., Embry, M.R., 2013. Alternatives to in vivo tests to detect endocrine disrupting chemicals (EDCs) in fish and amphibians - screening for estrogen, androgen and thyroid hormone disruption. Crit. Rev. Toxicol. 43, 45-72

Servos, M.R., Maguire, R.J., Bennie, D.T., Lee, H.B., Cureton, P.M., Davidson, N., Sutcliffe, R., Rawn, D.F.K., 2003. An ecological risk assessment of nonylphenol and its ethoxylates in the aquatic environment. Human Ecol. Risk Assess. 9, 569-587.

Shanle, E.K., Xu, W., 2011. Endocrine disrupting chemicals targeting estrogen receptor signaling: identification and mechanisms of action. Chem. Res. Toxicol. 24, $6-19$.

Stefansson, S.O., Haugland, M., Bjornsson, B.T., McCormick, S.D., Holm, M., Ebbesson, L.O.E., Holst, J.C., Nilsen, T.O., 2012. Growth, osmoregulation and endocrine changes in wild Atlantic salmon smolts and post-smolts during marine migration. Aquaculture 362, 127-136.

Strussmann, C.A., Nakamura, M., 2002. Morphology, endocrinology, and environmental modulation of gonadal sex differentiation in teleost fishes. Fish Physiol Biochem. 26, 13-29.

Sumpter, J.P., 2005. Endocrine disrupters in the aquatic environment: an overview Acta Hydrochim. Hydrobiol. 33, 9-16.

Tyler, C.R., Jobling, S., 2008. Roach sex, and gender-bending chemicals: the feminization of wild fish in English rivers. BioScience 58, 1051-1059.

Tyler, C.R., Jobling, S., Sumpter, J.P., 1998. Endocrine disruption in wildlife: a critica review of the evidence. Crit. Rev. Toxicol. 28, 319-361.

Tyler, C.R., Routledge, E.J., 1998. Oestrogenic effects in fish in English rivers with evidence of their causation. Pure Appl. Chem. 70, 1795-1804.

Tyler, C.R., Sumpter, J.P., 1996. Oocyte growth and development in teleosts. Rev. Fish Biol. Fish. 6, 287-318.

van Aerle, R., Pounds, N., Hutchinson, T.H., Maddix, S., Tyler, C.R., 2002 Window of sensitivity for the estrogenic effects of ethinylestradiol in early life-stages of fathead minnow, Pimephales promelas. Ecotoxicology 11 423-434.

von Schalburg, K.R., Yasuike, M., Yazawa, R., de Boer, J.G., Reid, L., So, S., Robb, A. Rondeau, E.B., Phillips, R.B., Davidson, W.S., Koop, B.F., 2011. Regulation and expression of sexual differentiation factors in embryonic and extragonadal tissues of Atlantic salmon. BMC Genomics 12, 31.

Woltering, D.M., 1984. The growth-response in fish chronic and early life stage toxicity tests - a critical review. Aquat. Toxicol. 5, 1-21. 